\title{
Meting van ultrasoniese pulssnelheid om die effektiwiteit van nabehandeling van kolherstel op beton te moniteer
}

\author{
Authors: \\ Johannes J. Bester ${ }^{1}$ \\ Deon Kruger ${ }^{1}$ \\ Affiliations: \\ ${ }^{1}$ Department of Civil \\ Engineering Science, \\ University of Johannesburg, \\ South Africa \\ Correspondence to: \\ Johannes Bester \\ Email: \\ jannesb@uj.ac.za \\ Postal address: \\ PO Box 524, Auckland Park \\ 2006, South Africa \\ Dates: \\ Received: 02 Dec. 2013 \\ Accepted: 28 July 2014 \\ Published: 13 Nov. 2014 \\ How to cite this article: \\ Bester, J.J. \& Kruger, \\ D., 2014, 'Meting van \\ ultrasoniese pulssnelheid \\ om die effektiwiteit \\ van nabehandeling van \\ kolherstel op beton te \\ moniteer', Suid-Afrikaanse \\ Tydskrif vir Natuurwetenskap \\ en Tegnologie 33(1), Art. \\ \#788, 6 pages. http://dx.doi. \\ org/10.4102/satnt.v33i1.788 \\ Copyright: \\ C) 2014. The Authors. \\ Licensee: AOSIS \\ OpenJournals. This work \\ is licensed under the \\ Creative Commons \\ Attribution License.
}

Read online:
Aangesien kolherstel op beton ' $n$ relatiewe nuwe veld in betoningenieurswese is, is daar slegs ' $n$ beperkte stel standaarde vir die uitvoer van sulke herstelwerk beskikbaar. Weens onvoldoende toetsmetodes van betonherstelwerk, is die toepassing van kwaliteitsversekering op sulke herstelareas dus beperk. Gepaste nabehandeling van betonherstelmateriaal het ' $n$ beduidende invloed op die kwaliteit van die herstelwerk en 'n streng nabehandelingsprosedure word gespesifiseer deur die vervaardiger van die betonherstelmateriaal. Die vraag ontstaan dus nou oor hoe daar verseker kan word dat die herstelmateriaal korrek volgens spesifikasie nabehandel word. Die noodsaaklikheid van 'n koste-effektiewe, niedestruktiewe toets vir die evaluering van die kwaliteit van kolherstel is ooglopend. In hierdie artikel word verslag gelewer oor 'n ondersoek na die gebruik van die meting van ultrasoniese pulssnelheid om die effektiwiteit van die nabehandeling op die kolherstel te bepaal. As deel van die eksperimentele werk is drie stelle van vier $1200 \mathrm{~mm}$ x $235 \mathrm{~mm}$ x $140 \mathrm{~mm}$ betonmonsters voorberei deur gebruik te maak van drie verskillende betonsterktes (30 MPa, $40 \mathrm{MPa}$ en $50 \mathrm{MPa}$ ). Die resultate het duidelik getoon dat daar' $n$ afname is in die sterkte-ontwikkeling van betonherstelmateriaal waar daar onvoldoende nabehandeling toegepas is. Swak nabehandeling het tot gevolg gehad dat daar ' $n$ afname in die lesings van die ultrasoniese pulssnelheid was weens die laer digtheid en swakker sterkteontwikkeling van die herstelmateriaal. Hierdie bevinding is bevestig deur ooreenstemmende resultate te verkry vanaf aftrektoetse wat uitgevoer is om die bindsterkte tussen die kolherstelmateriaal en die in situ beton te bepaal. Die meting van die ultrasoniese pulssnelheid stel dus 'n effektiewe en vinnige, niedestruktiewe toetsmetode voor wat gebruik kan word vir die voorspelling van die kwaliteit van die kolherstel en kan as kwaliteitsbeheermeganisme van kolherstel in 'n vroeë stadium van die produk se lewensiklus aangewend word.

The use of ultrasonic pulse velocity measurements to monitor the effectiveness of concrete patch repairs. Concrete patch repairing is a fairly new field in the concrete industry, so that there is only a limited number of standards available. Consequently there is also limited application of quality assurance for patch repairs. Curing has a major effect on the quality of the repair work; therefore the manufacturer of patch repair materials has very stringent guidelines with regards to curing methods. The question now is: How can it be ensured that the repair material was cured according to specification? So a need for a cost-effective, nondestructive test for the evaluation of the quality of patch repairing exists. This article presents the results of a research project on the use of ultrasonic pulse velocity to evaluate the quality of curing on concrete patch repairs. As part of the experimental work, three sets of four $1200 \mathrm{~mm} \times 235$ $\mathrm{mm} \times 140 \mathrm{~mm}$ concrete test specimens were prepared in three concrete strengths $(30 \mathrm{MPa}, 40$ $\mathrm{MPa}$ and $50 \mathrm{MPa}$ ). The results clearly indicate that there is a decline in the pulse velocities when inadequate curing is performed. This is due to the lower densities and poor strength development of the inadequately cured concrete patch material. This conclusion is supported by the corresponding pull-off tests that were done to determine the bond strength between the in situ concrete and concrete repair material. The measuring of the pulse velocities therefore proved an effective and fast nondestructive method to estimate the quality of concrete patch repairs, and can be used as a quality control method at the early stages of disrepair.

\section{Inleiding}

Op enige gebied van ingenieurswese is dit algemene praktyk dat daar aan die verskeie nasionale en internasionale standaarde, kodes en spesifikasies voldoen moet word (Concrete Society [C\&CI] 1991). Hierdie vereistes bestaan om die kwaliteit, duursaamheid en veiligheid van dienste, projekte en produkte te verseker. Die nakoming van hierdie vereistes word gekontroleer deur verskeie toetse en metings, wat deur dié kodes gespesifiseer word. 
Aangesien kolherstel op beton 'n relatiewe nuwe veld in betoningenieurswese is, is daar slegs ' $n$ beperkte stel standaarde en kodes vir die uitvoer van sulke herstelwerk beskikbaar (Cusson \& Mailvaganam 1996; Faris, Nassif \& Affouni 2003; Kay \& Regan 1987). Verskeie navorsingprojekte is gedoen om sulke standaarde en kodes te genereer, en om gepaste toetsprosedures te ontwikkel om veral die duursaamheid te kontroleer (Austin \& Robins 1993; De Belie, Grosse \& Reinhard 2005; Pearson-Kirk \& CollardJenkins 2003; Lancon, Piot \& Scansites 2003). Tot op datum is daar egter steeds 'n gebrek aan 'n vinnige, koste-effektiewe en aanvaarbare, niedestruktiewe toetsprosedure om die langtermynduursaamheid van betonkolherstel te bepaal of te voorspel. Geeneen van die bestaande toetsmetodes is algemeen aanvaarbaar bevind nie en word dus nie effektief toegepas of aangewend nie.

\section{Agtergrond}

Die snelle vooruitgang die afgelope 25 jaar in die betonherstelindustrie het 'n vinnig ontwikkelende mark teweeg gebring, en daarmee saam 'n toenemende behoefte aan verbetering wat betref herstelmateriaal, ontwerpmetodes, installeringspraktyke en -prosedures, kontrakteringsprosesse, asook kwaliteitsversekering, kwaliteitsbeheer en -opleiding van kontrakteurs (Cusson \& Mailvaganam 1996).

Alhoewel baie aandag gegee word aan die verbetering van die kwaliteit van die herstelmateriaal, is die vakmanskap tydens die installering van die kolherstelwerk van die uiterste belang vir die duursaamheid en dus die langtermynsukses van die herstelwerk. Weens onvoldoende of oneffektiewe toetsmetodes en kwaliteitsassessering van betonherstelwerk, is die nagaan en toepassing van kwaliteitsversekering op sulke herstelareas egter beperk. Gepaste nabehandeling van betonherstelmateriaal het ' $n$ beduidende invloed op die kwaliteit van die herstelwerk en daarom spesifiseer die meeste betonherstelmateriaal-vervaardigers, 'n spesifieke nabehandelingsprosedure wat ná gebruik van hul produk gevolg moet word. Die vraag ontstaan dus nou oor hoe die toesighoudende ingenieur of kontrakteur kan verseker dat die herstelmateriaal korrek volgens spesifikasie geïnstalleer en nabehandel word. Die noodsaaklikheid van 'n aanvaarbare en koste-effektiewe, niedestruktiewe toets vir die evaluering van die kwaliteit van kolherstel om die duursaamheid daarvan te verseker, is ooglopend (Faris et al. 2003; Kay \& Regan 1987; Pearson-Kirk, CollardJenkins \& Solan 2003).

\section{Betonkolherstelsisteme}

Die doel van kolherstelwerk aan die oppervlakte van staalversterkte betonstrukture is om 'n ekonomiese langtermynoplossing vir betonverweringsprobleme te verseker. Om hierdie doelwit te bereik, bestaan daar verskeie metodes wat gevolg kan word om te verseker dat die herstelwerk wel duursaam en dus suksesvol is. Die basiese kolherstelproses behels drie belangrike komponente (assessering, keuse van materiaal en installering) en sluit die volgende stappe in:

- assesseringsondersoek na die algemene toestand van die struktuur

- diagnostiese ondersoek om die oorsaak van die probleem te bepaal

- bepaling van die omvang en doelwitte van die herstelprojek

- selektering van die aangewese kolherstelmetodes en -produkte

- omskrywing van die toekomstige instandhoudingsbehoeftes en -prosedures

- uitvoering van die gekose herstel-en rehabilitasieprosesse met geskikte kwaliteitsbeheer.

Kolherstelmetodologieë word deur elke kolherstelmateriaalvervaardiger voorgeskryf en is spesifiek gebaseer op hul produkvereistes. Hierdie metodologieë skryf noukeurig voor hoe die voorbereiding vir die herstelarea en spesifiek die voorbereiding vir die betonsubstraat gedoen moet word. Die meng, aanwending en verdigting van die kolherstelmateriaal, asook die spesifieke nabehandelingmetodes (kuringmetodes) ten opsigte van hul produk word ook noukeurig gespesifiseer.

\section{Tipes betonkolherstelfalings}

Betonkolherstelmislukkings kom voor wanneer een of meer van die drie bogenoemde herstelsisteemkomponente nie die korrekte of voldoende aandag geniet het nie. Baie dikwels
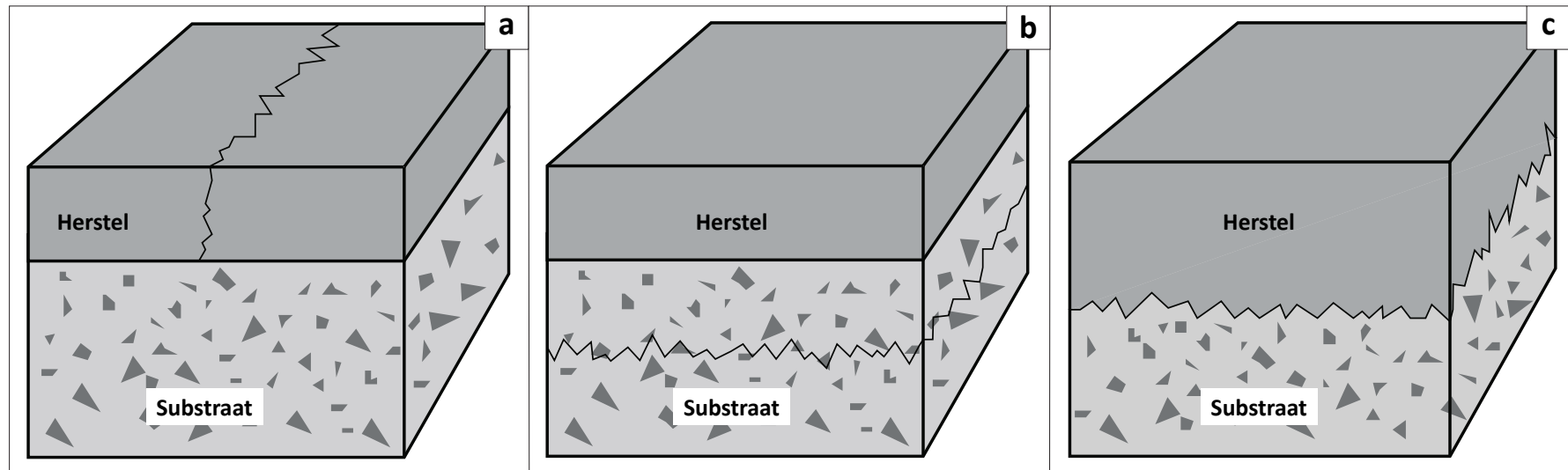

FIGUUR 1: Betonkolherstelfalingstipes. (a) Dwarskraak in herstelmateriaal, (b) longitudinale kraak in betonsubstraat en (c) longitudinale kraak op die bindingsvlak. 
is die mislukking toe te skryf aan verkeerde installering en onvoldoende nabehandeling. Sulke mislukkings het tot gevolg dat daar'n gebrek aan duursaamheid van diekolherstel is, wat dikwels sigbaar is as mikro- of makrokraakpatrone, afskilfering of afsplintering van die herstelmateriaal asook 'n algemene verlies aan sterkte. Figuur 1 toon sommige van die algemeenste, kraakverwante kolherstelfalings aan.

\section{Huidige betonkolhersteltoetse}

Die kwaliteitsbeheertoetse wat tans in gebruik is vir kolhersteltoetswerk is beperk en nie koste-effektief nie. Hierdie toetse behels niedestruktiewe toetsing wat tydrowend is en steeds ook blootgestel is aan inherente onakkuraathede wat dus opgevolg moet word deur verdere destruktiewe toetse wat verdere herstelwerk ná afloop van die toets vereis. Huidige toetsmetodes vir betonkolherstelwerk sluit in uittrektoetse, die Queens University-toets, asook gedeeltelike kerntoetse en deurdringing (absorpsie en permeabiliteitstoetse [Malhorta \& Carino 2004]). Hierdie toetse meet die volume waterabsorpsie oor ' $n$ lang tydperk en is dus tydrowend, met resultate slegs beskikbaar vir analise na 'n verlengde tydperk. Die probleem met hierdie toetsmetodes is dat' $n$ monster van die oorspronklike produk

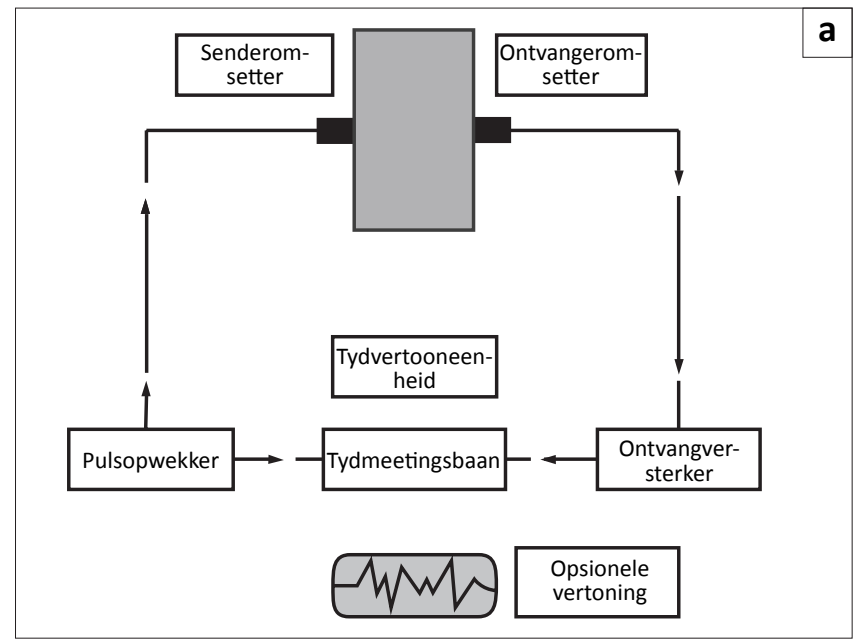

FIGUUR 2: Diagram van pulssnelheidsopstelling. benodig word en dat die monster verteenwoordigend moet wees van die hele kolherstelarea wat behandel word. Hierdie vereiste veroorsaak dat kerns geboor moet word om die verteenwoordigende monsters te verkry, wat dus tot 'n destruktiewe toetsmetode lei. Die voorgestelde meting van die ultrasoniese pulssnelheid wat in hierdie artikel bespreek word, sal aandag aan die meeste van bogenoemde probleme gee.

\section{Niedestruktiewe toetsing Ultrasoniese pulssnelheid}

Die ontwikkeling van toetsing deur die meting van die ultrasoniese pulssnelheid deur beton het sy oorsprong in Kanada en Engeland tydens die Tweede Wêreldoorlog gehad. Moderne pulssnelheidsapparate bestaan uit 'n metode om 'n golfpuls te genereer met transmissie van hierdie puls tot in die beton (pulsopwekker en versenderomsetter), asook 'n manier om die opgewekte puls waar te neem (ontvangeromsetter) ná transmissie deur die beton. Die stelsel maak die akkurate meting van die tyd moontlik wat dit die puls neem om deur die beton te beweeg. Die sisteem gebruik hierdie gemete tyd $(\Delta t)$ om die snelheid van die golf te bepaal. Figuur 2 stel hierdie sisteem diagrammaties voor.

Die relatiewe snelheid van die ultrasoniese puls word tydens die transmissie deur die betonmatriks beïnvloed deur verskeie aggregaatmortelgrenslyne en ander diskontinuïteite. Vir die versendingsomsetter om effektief te werk, word 'n skoon en gladde kontakoppervlak op die beton vereis om aanvaarbare kontak tussen die sensor en die beton te bewerkstellig. Petroleumjellie word algemeen gebruik as smering en kontakmiddel op die betonoppervlak. Sodoende word 'n akkurater lesing verkry.

\section{Pulssnelheidsmetingopstelling}

Daar is drie moontlike maniere waarop die versending- en ontvangeromsetters opgestel kan word. Hierdie metodes word beskryf as die direkte, semidirekte en indirekte metodes en word aangetoon in Figuur $3(\mathrm{a}-\mathrm{c})$.

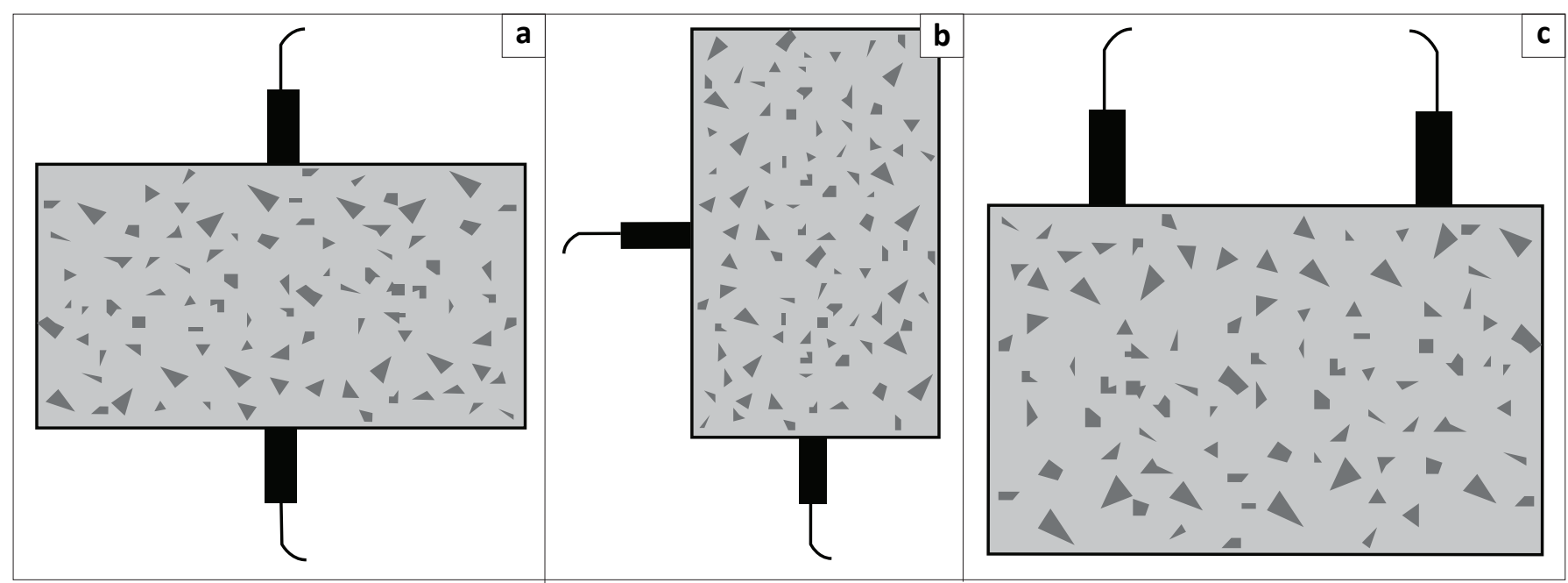

FIGUUR 3: Pulssnelheidsopstellingsdiagram. (a) direk, (b) semidirek en (c) indirek. 
Die direkte versendingsmetode, Figuur 3(a), is die mees gewenste vir akkurate metings. Die semidirekte metode is ook aanvaarbaar, maar sorg moet gedra word om te verseker dat die omsetters nie te ver van mekaar af verwyder is nie, andersins kan die versende puls in so 'n mate verswak dat dit nie bespeur kan word nie. Die indirekte metode is die mees onaanvaarbare, aangesien die versende sein aansienlik swakker is by die ontvanger as by die direkte metode.

\section{Faktore wat pulssnelheid beïnvloed}

Sommige van die belangrikste faktore wat die snelheid van die ultrasoniese puls sal beïnvloed, is die tipe aggregaat in die beton, die grootte en gradering van die aggregaat, die sementtipe, die verhouding van water tot sement, die gebruik van chemiese bymiddels, die ouderdom van die beton, die kwaliteit van die versender- en ontvangeromsetterkontak, die voginhoud van die beton, die pulspadlengte, die grootte en vorm van die monster, die vlak van spanning in die monster en die posisie van die staalbewapening. Diskontinuïteite, soos krake of invoegsels in die beton, beïnvloed ook die pulstransmissietyd.

\section{Eksperimentele ontwerp}

Drie stelle van vier $1200 \mathrm{~mm} \mathrm{X} 235 \mathrm{~mm} \mathrm{X} 140 \mathrm{~mm}$ betonmonsters is voorberei deur gebruik te maak van drie betonsterktes (30 MPa, $40 \mathrm{MPa}$ en $50 \mathrm{MPa}$ ). Elke monster is voorsien van 'n enkele Y20-staalbewapeningstaaf in die middel van die monster met 'n dekking van $30 \mathrm{~mm}$, soos aangetoon in Figuur 4. Die betonmonsters is vir 7 dae gekuur deur onderdompeling in water teen $22{ }^{\circ} \mathrm{C}-25^{\circ} \mathrm{C}$. $\mathrm{Na}$ verwydering uit die water is die kolherstelareas gesny en voorberei. Kolherstel met die onderskeie produkte is volgens die produkverskaffer se voorskrifte uitgevoer nadat die betonmonsters 28 dae oud was.

Die betonmengselontwerp vir die in situ betonsubstraat word getoon in Tabel 1. CEM I 42.5- sement is gebruik met riviersand en $19.0 \mathrm{~mm}$-klip as aggregate.

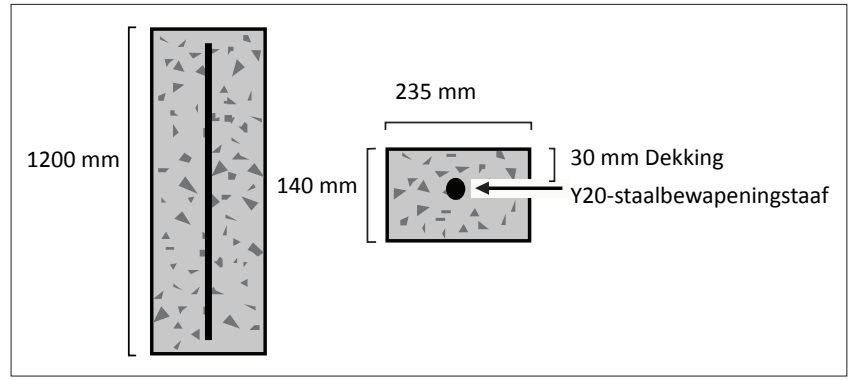

FIGUUR 4: Betonmonsterontwerp.
Die gespesifiseerde kolherstelwerkmetode soos voorgeskryf deur die herstelmateriaalverskaffer is op elk van die monsters noukeurig gevolg. Addisioneel tot die drie industriële produkte (A, B en C) is die herstelmetode soos deur die Concrete Society (C\&CI 1991) gespesifiseer word, ook gevolg. Figuur 5 toon die posisies aan van die drie onderskeie kolherstelareas per betonmonster. Die boonste area is $100 \%$ volgens die voorskrifte van die verskaffers nabehandel, die middelste kolherstel is vir slegs $50 \%$ van die gespesifiseerde tyd van die verskaffers nabehandel, terwyl die derde posisie die area aandui waar daar geen nabehandeling $(0 \%)$ op die kolherstel toegepas is nie. Nabehandeling vir die nywerheidsprodukte het die aanwending van 'n seëllaag behels, terwyl die C\&CImetode bedekking van die kolherstel met 'n laag plastiek behels het. Geen verdere nabehandeling van die in situ beton het plaasgevind nie.

Nadat die nabehandeling toegepas is soos hierbo bespreek, is daar metings gedoen van die ultrasoniese pulssnelheid, asook aftrektoetse, volgens ASTMC1583 met skywe van $50 \mathrm{~mm}$ deursnee op die kolherstelareas. Daar is gebruik gemaak van die direkte metingsmetode om die pulssnelheidslesings te bepaal. Hierdie lesings is direk oor die staalbewapening geneem op elk van die verskillende nabehandelingsareas. Ná afloop van die pulssnelheidsmetings is die meganiese aftrektoetse met 'n skyf van $50 \mathrm{~mm}$ gedoen op elk van die herstelareas by die verskeie nabehandelingsareas. Die meettoerusting wat gebruik is, het die Proceq Dyna Aftrektoetser en die Proceq TICO Ultrasoniese Pulssnelheidmeter ingesluit.

\section{Resultate}

Die resultate van die meting van die ultrasoniese pulssnelheid vir elk van die betonsterktes word aangetoon in Figure 6-8. Daar kan duidelik gesien word dat soos die persentasie nabehandeling afneem, daar 'n ooreenstemmende en betekenisvolle afname in die gemete pulssnelheid (UPS) waarneembaar is. Hierdie afname in

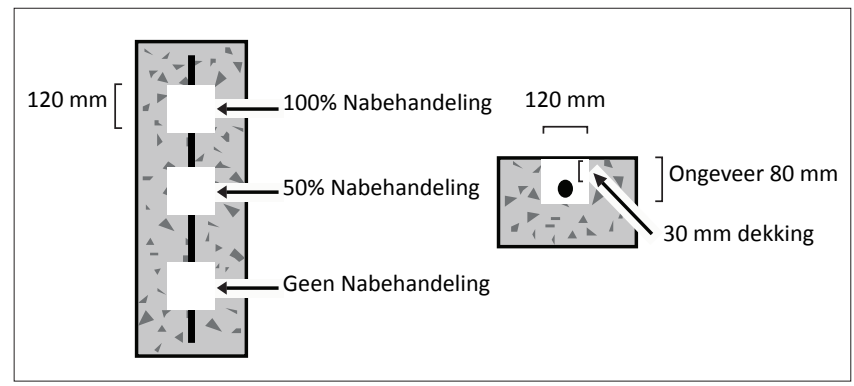

FIGUUR 5: Kolherstelareas per betonmonster.

TABEL 1: Betonmengselontwerp.

\begin{tabular}{llll}
\hline Betondruksterkte & $\mathbf{3 0} \mathbf{M p a}$ & $\mathbf{4 0} \mathbf{M P a}$ & $\mathbf{5 0} \mathbf{M P a}$ \\
\hline Water $\left(\mathrm{kg} / \mathrm{m}^{3}\right)$ & 225 & 225 & 225 \\
Sement $\left(\mathrm{kg} / \mathrm{m}^{3}\right)$ & 271 & 336 & 402 \\
Riviersand $\left(\mathrm{kg} / \mathrm{m}^{3}\right)$ & 782 & 734 & 685 \\
$19 \mathrm{~mm}-\mathrm{klip}\left(\mathrm{kg} / \mathrm{m}^{3}\right)$ & 929 & 929 & 929 \\
\hline
\end{tabular}


pulssnelheid is waarneembaar in elk van die drie verskillende betonsubstraatsterktes, asook vir al die herstelmateriale wat gebruik is, afgesien van produk B waar daar'n onverklaarbare uitskieter by $0 \%$ nabehandeling waarneembaar is.

Figure 9-11 toon die resultate aan van die onderskeie aftrektoetse uitgevoer op die drie verskillende herstelprodukte by elk van die drie nabehandelingstoestande. Daar kan gesien word dat die afname in die aftreksterkte in ooreenstemming is met die verminderde nabehandeling wat op die herstelmateriaal

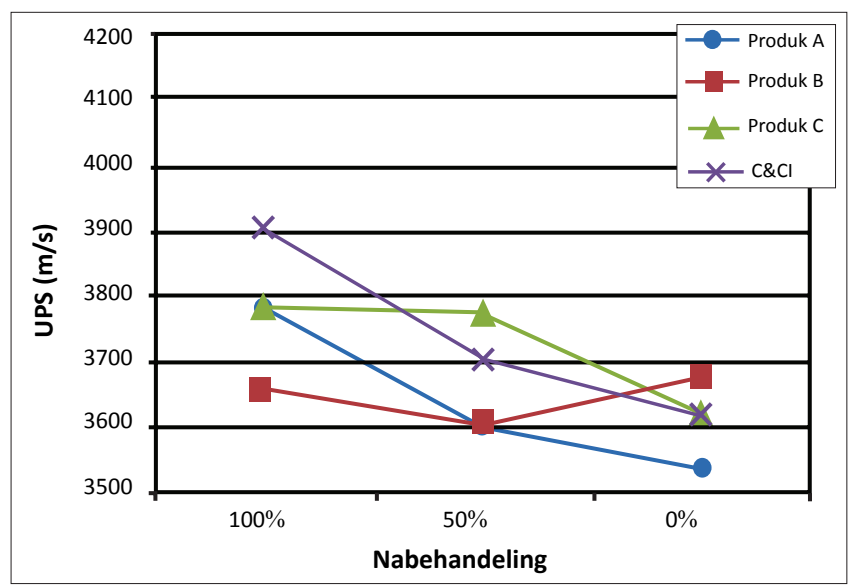

FIGUUR 6: Ultrasoniese pulssnelheid-resultate vir $30 \mathrm{MPa}$-betonsubstraat.

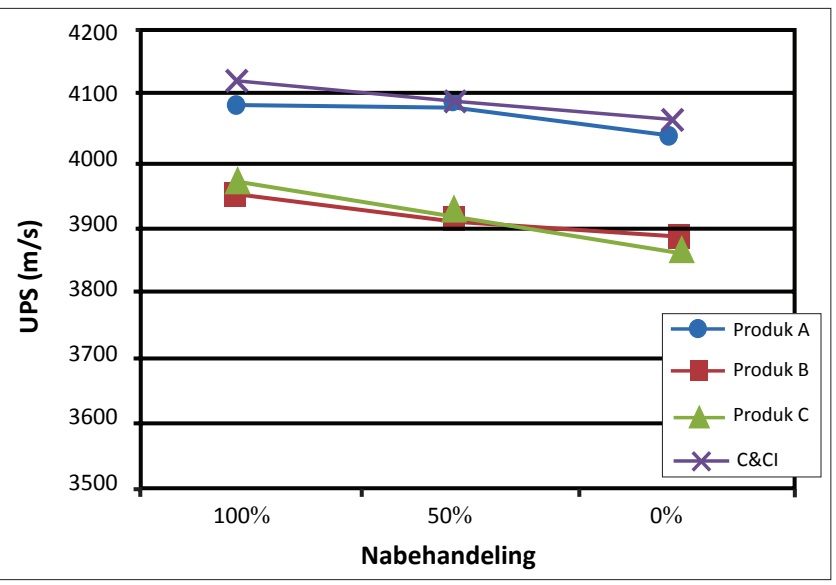

FIGUUR 7: Ultrasoniese pulssnelheid-resultate vir $40 \mathrm{MPa}$-beton.

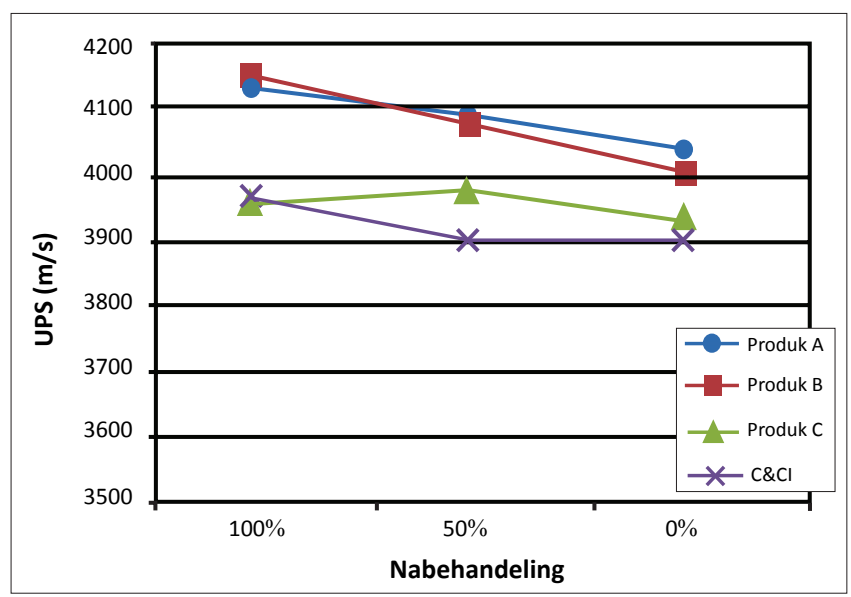

FIGUUR 8: Ultrasoniese pulssnelheid-resultate vir $50 \mathrm{MPa}$-beton. toegepas is. Dit is waar vir elk van die betonsterktes, asook vir die drie verskillende produkte en hul herstelmetodologieë wat gevolg is.

\section{Gevolgtrekking}

Die resultate hierbo toon duidelik dat daar 'n afname is in die sterkte-ontwikkeling van betonherstelmateriaal wanneer onvoldoende nabehandeling op die herstelmateriaal toegepas is. Hierdie swak nabehandeling het tot gevolg dat daar ' $n$ afname in die lesings van die ultrasoniese

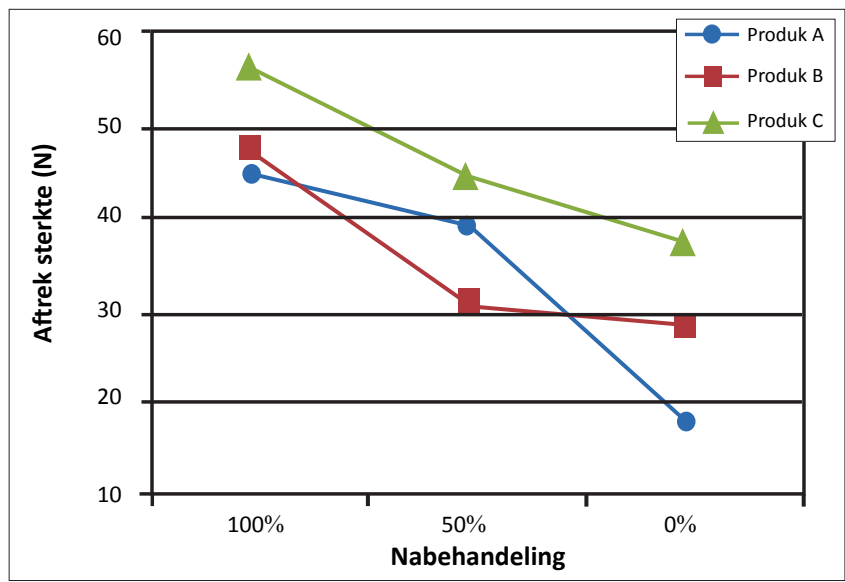

FIGUUR 9: Oppervlakaftrektoetse vir 30 MPa-beton.

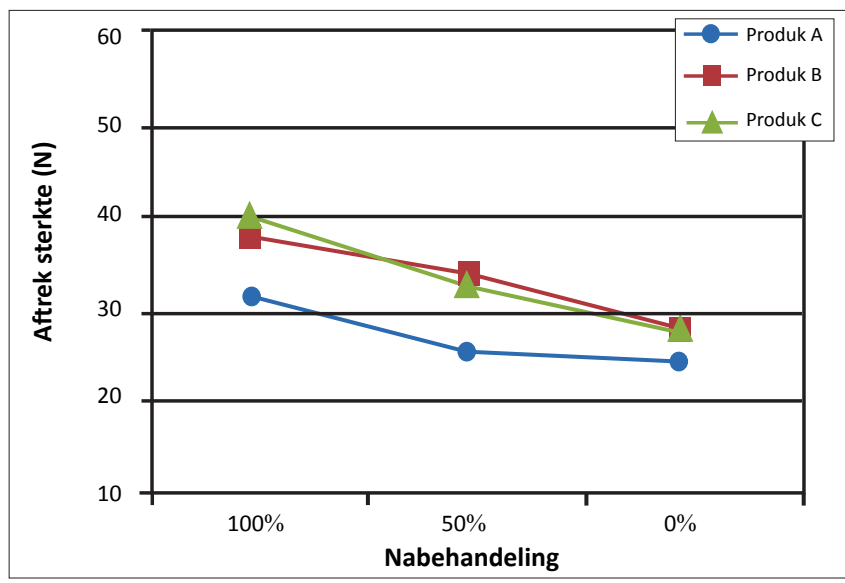

FIGUUR 10: Oppervlakaftrektoetse vir 40 MPa-beton.

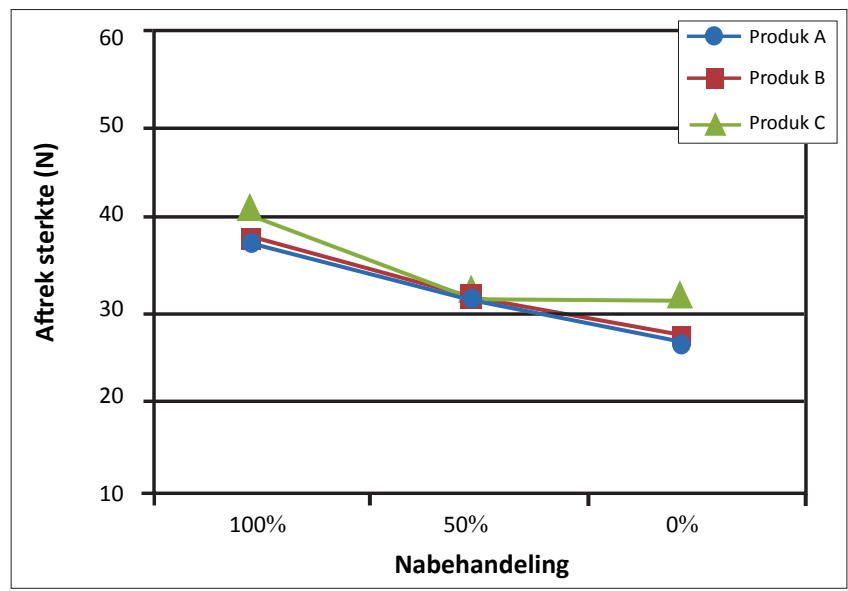

FIGUUR 11: Oppervlakaftrektoetse vir $50 \mathrm{MPa}$-beton. 
pulssnelheid is weens die laer digtheid en swakker materiaalsterkte-ontwikkeling. Hierdie bevinding word bevestig deur die ooreenstemmende resultate wat gekry is vanaf die aftrektoetse gedoen om die bindsterkte tussen die herstelmateriaal en die in situ betonsubstraat te meet. Metings van die ultrasoniese pulssnelheid deur betonkolherstelwerk weerspieël direk die sterkte- en digtheidsontwikkeling wat weer direk verband hou met die nabehandeling wat op die kolherstelwerk toegepas is.

Die meting van die ultrasoniese pulssnelheid (UPS) is dus 'n effektiewe en vinnige niedestruktiewe toetsmetode wat gebruik kan word vir die kwaliteitsbeheer van die korrekte toepassing van die voorgeskrewe nabehandeling op betonherstelareas. Dit kan dus dien as kwalitatiewe evaluering van 'n betonherstelarea vir gebruik as 'n goedkeuringsmeganisme deur die toesighoudende ingenieur of kliënt sowel as om die kwaliteit van kolherstel te voorspel.

\section{Erkenning \\ Mededingende belange}

Die outeurs verklaar hiermee dat hulle geen finansiële of persoonlike verbintenis het met enige party wat hulle voordelig of nadelig in die skryf van hierdie artikel kon beïnvloed nie.

\section{Outeursbydrae}

J.J.B. (Universiteit Johannesburg) is die projekleier, en is verantwoordelik vir die eksperimentele ontwerp. J.J.B. het die eksperimente ook uitgevoer. D.K. (Universiteit Johannesburg) en J.J.B. het die manuskrip gesamentlik geskryf.

\section{Literatuurverwysings}

Austin, S.A. \& Robins, P.J., 1993, 'Development of patch repair test to study behaviour of shallow concrete patch repairs', Magazine of Concrete Research 45(164), 221229. http://dx.doi.org/10.1680/macr.1993.45.164.221

Concrete Society $(\mathrm{C} \& \mathrm{Cl})$, 1991, Patch repair of reinforced concrete - subject to reinforcement corrosion: Model specification and method of measurement, The Concrete Society, Slough.

Cusson, D. \& Mailvaganam, N., 1996, 'Durability of repair materials', Concrete International, March 1996, Repair of aging concrete structures workshop, 27-28 International, February, 1997.
Fero

De Belie, N., Grosse C.U. \& Reinhard, H.W., 2005, 'Ultrasound monitoring of setting and hardening of shotcrete including alkali-rich or alkali-free accelerators' Concrete repair, rehabilitation and retrofitting: Proceedings of the International conference on concrete repair, rehabilitation and retrofitting (ICCRRR), Cape Town, South Africa, 21-23 November, 2005.

Faris, A.M., Nassif, H.N. \& Affouni, S.A., 2003, 'The effect of the concrete substrate temperature on the properties of patch repair materials', Proceedings of the 1st International conference on concrete repair, Volume 2, St. Malo, France, 15-17 July, 2003.

Kay, E.A. \& Regan, J., 1987, 'Acceptance and compliance testing of patch repair repair of reinforced concrete, Arabian Gulf, 11-13 October, 1987.

Lancon, H., Piot, S. \& Scansites, T.M., 2003, 'A new tool for remote visual inspection', Concrete Solutions: 1st International conference on concrete repair, Volume 1, St. Malo, France, 15-17 July, 2003.

Malhorta, V.M. \& Carino, N.J., 2004, Handbook on non-destructive testing of concrete, 2nd edition, CRC Press LLC, West Conshohocken, PA.

Pearson-Kirk, D., Collard-Jenkins \& S., Solan, B., 2003, 'Cost effective testing of concrete
structures', Proceedings of concrete solutions: 1st International conference on concrete repair, Volume 1, St Malo, France, 15-17 July, 2003. 